\title{
Mediation Impact of Marketing Intelligence in the Relationship between Technology Based Knowledge Sharing and Product Innovation
}

\author{
Adel Odeh AL-Hashem \\ Al- Balqa Applied University, Amman College, Amman, Jordan
}

\begin{abstract}
Technology based knowledge sharing and marketing intelligence have both emerged as an important driver to deliver innovative products comparing with competitors. The study seeks to identify not only the impact of Technology based knowledge sharing and marketing intelligence on product innovation, but to examine the mediation impact of marketing intelligence between study variables as well. A convenience sampling technique of (106) senior and middle managers who are dealing with knowledge sharing practices and marketing intelligence in Jordanian pharmaceutical companies is described. The findings confirmed the mediation effect of marketing intelligence in the relationship between study variables. Therefore, adoption Technology based knowledge sharing and marketing intelligence could create innovative product.
\end{abstract}

Keywords -Marketing Intelligence, Technology Based knowledge Sharing, Product Innovation

\section{Introduction}

Knowledge sharing refers to the process which tacit or explicit knowledge that is communicated among individuals through interaction with coworkers to solve problems in an effective methods at the individual level, and sharing knowledge where and when needed to other members at the organization level [1].

DOI: 10.18421/TEM92-35

https://doi.org/10.18421/TEM92-35

Corresponding author: Adel Odeh AL-Hashem, Al-Balqa Applied University, Amman, Jordan.

Email: adelalhashm@bau.edu.jo

Received: 11 November 2019.

Revised: 16 April 2020.

Accepted: 22 April 2020.

Published: 27 May 2020.

(cc) BY-NC-ND (C) 2020 Adel Odeh AL-Hashem; published by UIKTEN. This work is licensed under the Creative Commons Attribution-NonCommercial-NoDerivs 4.0 License.

The article is published with Open Access at www.temjournal.com
Accordingly, Technology plays a crucial transformational role in changing business nature and supporting knowledge sharing among business partners in the real time around the world. Hence, the sharing of knowledge is considered as a process of knowledge exchange among organization members in order to play a significant role in workforce behavior for maximizing organization's ability of providing solutions to achieve goals and sustaining the competitive advantage. Knowledge can be either explicit knowledge which easily can be expressed and shared or tacit knowledge which cannot be easily shared and articulated one hundred percent [2]. Hence, information technology is a key issue to assist the organization in managing knowledge resources efficiently. Due to turbulent business environment and globalization caused by strong competition in the marketplace new challenges are created and pressures on business firms as well. Thus, technology-based knowledge sharing became the key initiative to responding to market pressures and gain sustainable competitive advantage. In order to enter new markets, companies maximize market intelligence capabilities to differentiate itself from others through providing innovative products in the marketplace. However, despite the nurturing and encouragement of technology based knowledge sharing, many Jordanian companies are not effectively utilizing emerging technology and knowledge sharing systems .The purpose of this paper is contributing literature related to knowledge sharing, marketing intelligence and product innovation in order to investigate the mediating impact of marketing intelligence between technologies based knowledge sharing and product innovation.

\section{Literature Review and Hypotheses Development}

\subsection{Technology Based Knowledge Sharing}

Recent turbulent and dynamic business environment forces business firms to sense rapidly changing environment and quickly respond through using 
innovative strategies in order to become leader in the marketplace [3]. Information and telecommunication technologies, considered as an essential and enabler tools, can assist business firms to overcome and force the environment pressures through using advanced information and communication technology supporting knowledge sharing process for the purpose of creating innovative ways and idea to attain winning position in such dynamic and changing environment [4]. Information sharing systems play an important role in reshaping and redesigning business processes, enhancing work flow including knowledge flow among business units internally, and with business partners externally enabling digital knowledge sharing of business firms [5]. Therefore, the extensive uses of advanced technology increase the amount of information and create a huge amount of data, at the same time facilitate quick reach to data and information resources [6]. However, information technology is becoming increasingly important communication tools that Transferring data, information and knowledge among business members and its partners to generate new ideas, which can be useful in facilitating knowledge exchange via networking systems operating across thousands of machines such as accessing the worldwide web, business intranets and databases [7]. In addition, knowledge socialization through the use of a communication medium can assist collaboration among project teams solving problems and enabling the development of new knowledge for innovation [8]. Accordingly, Technology plays a crucial transformational role in changing business nature and enabling knowledge sharing among interested parties.

\subsubsection{Explicit knowledge exchange}

Knowledge exchange refers to transfer or communicate explicit knowledge between individuals, groups, organizations [2], [9]. It can be done easily through several means either traditional means such as manual, documents, books or technological means that support exchange, groupware, web based access to data, databases and information repository such as best practices databases, expert locater systems and lesson learned systems through formal training in order to enhance the ability of employees doing their tasks in innovative way [10].

\subsubsection{Tacit knowledge Socialization}

Tacit knowledge socialization is the integration multiple streams and synthesis of tacit knowledge among individuals using joint activities instead of verbal or written instructions. There is difficulty in expressing tacit knowledge directly in words [1], it can be done by traditional means such as employees rotation, conferences and brain storming or facilitate socialization through technological tools that enhance quality of the workers outcomes such as video conferencing, electronic email and electronic discussions [10].

In summary, knowledge sharing process was found in several studies that have significant impact on business performance as a whole including marketing intelligence and product innovation [12]. Therefore, the study predicted that:

H1: Technology based knowledge sharing has a significant impact on marketing intelligence.

H2: Technology based knowledge has a significant impact on product innovation.

\section{Marketing Intelligence}

Business firms face a stiff competition in the global business environment. These changes and pressures force business firms to respond in an innovative manner sustaining competitive advantage in the marketplace [13]. Market intelligence refer to business ability to information processing, interpreting and disseminating to enhance the coordination process among business partners being agile to respond to changing environment in order to enter new markets that have to maximize market intelligence capabilities which require details knowledge of competitors, best practices through capturing and processing relevant information about specific market environment [14]. Therefore, marketing intelligence is information about the business environment that support decision makers in the process of developing their marketing strategies according to surrounding environment. The marketing intelligence required understanding the market needs including competitors and customers information through using information technologies to systematically collect and analysis of data about business environment from several sources, and provide it to decision makers who use it for take better actions [15]. Thus, business firms should take into account the importance of continuously scanning and monitoring market needs in order to exploit the opportunities for the purpose of being leader in the market and avoid threats to minimize the business risk sustaining competitive advantage. Also, collecting information about market is very important and ongoing process, maximizing competitive ability and competition position in the market. Due to a huge amount of marketing data and developing new technology tools new opportunities are created for business firms to make more on in depth assessment of customer's needs using marketing intelligence systems. Marketing intelligence systems considered important tools to capturing relevant data for marketing managers under 
uncertainty to provide more complete information, as well as the storage capacity and information retrieving of marketing intelligence systems allow wider variety of data being gathered and used. However, Emerging and advanced technologies enable business firms capturing, process, analyze, disseminate a huge amount of customer data to remain close relationship to customers in order to update intelligence and predict new market requirement [16]. Thus, in this research paper, it is expected that:

H3: Marketing intelligence has a significant impact on product innovation.

H4: Marketing intelligence has a mediation impact between technology-based knowledge sharing and Product innovation.

\section{Product Innovation}

Products innovation considered an important term that can provide opportunities for business growth and improving the product features to gain sustainable competitive advantage in the market [17]. Product innovation refers to "the novelty and meaningfulness of new products introduced to the market at a timely fashion" [18]. Based on the previous literature product innovation which considered the developing of new products and improving the existing products using new techniques in the production process, we can state that product innovation is a strategic component of business ability to succeed and be able to gain high market share in the turbulent business environment. Therefore, the ultimate goal of product innovation is developing new products with different specifications or improving the existing product to meet customer needs. On the other hand, product success depends on product innovativeness that can meet the consumer's preferences through introducing and designing competitive products to maintain customer loyalty. Also, Product innovation is a strategy involving commercial, technical design and production efforts to create a unique product that includes new ingredients in the market. Thus, a product can be viewed as innovative when it introduces new value which is impossible to imitate due to the uniqueness of product compared with the products pushed in the market. This is based onthe study predicted that product innovation might be enhanced as a dependent variable through adopting technology based knowledge sharing and marketing intelligence concepts.

\section{Research Methodology}

\subsection{Study Population and Sample}

The target of the study is senior and middle managers who are dealing with technology-based knowledge sharing practices and marketing intelligence in the pharmaceutical companies in Jordan. A convenience sampling technique was used for this purpose, according to Mills and Smith (2011) stated that highly educated sample is suitable for studies that required awareness for knowledge management practices in the business.

\subsection{Data Collection}

For data collection this study employed questionnaire. The instrument we used is five-point Likret scale from (1) strongly disagrees and (5) strongly agree to examine study hypotheses as shown in table (1). Total of (125) questionnaires were distributed to the researched sample and (106) usable questionnaires were returned for analysis purpose. Pilot study was employed as well as Cronbach's Alpha to measure the internal consistence reliability of the questionnaire as shown in the Table (1) is $0.842,0.884$ and 0.823 respectively. It means that the questionnaire has high internal consistence reliability.

Table 1. Structure of Instruments and Cronbach's Alpha results

\begin{tabular}{|c|c|c|c|c|}
\hline Variable & $\begin{array}{c}\text { Item } \\
\text { No }\end{array}$ & Item & $\begin{array}{l}\text { Cronbach's } \\
\text { Alpha }\end{array}$ & Author \\
\hline \multirow{5}{*}{$\begin{array}{c}\text { Technology } \\
\text { based knowledge } \\
\text { Sharing (TBKS). } \\
\text { (K. Exchange) }\end{array}$} & 1 & $\begin{array}{l}\text { The company members use telecommunication networks } \\
\text { to exchange the latest innovations in the marketplace. }\end{array}$ & & \multirow{6}{*}{ [19] } \\
\hline & 2 & $\begin{array}{l}\text { Based technology explicit knowledge exchange is a } \\
\text { formal practice among company members. }\end{array}$ & & \\
\hline & 3 & $\begin{array}{l}\text { The company utilizes computer-based systems to access } \\
\text { and exchange information from inside and outside. }\end{array}$ & & \\
\hline & 4 & $\begin{array}{l}\text { The company support sharing of best practices between } \\
\text { individuals and exchange of knowledge. }\end{array}$ & & \\
\hline & 5 & $\begin{array}{l}\text { Our company members are linked by single knowledge } \\
\text { base to solve problems. }\end{array}$ & & \\
\hline & 6 & $\begin{array}{l}\text { The company use teleconferences to share knowledge } \\
\text { among employees to generate new ideas. }\end{array}$ & & \\
\hline
\end{tabular}




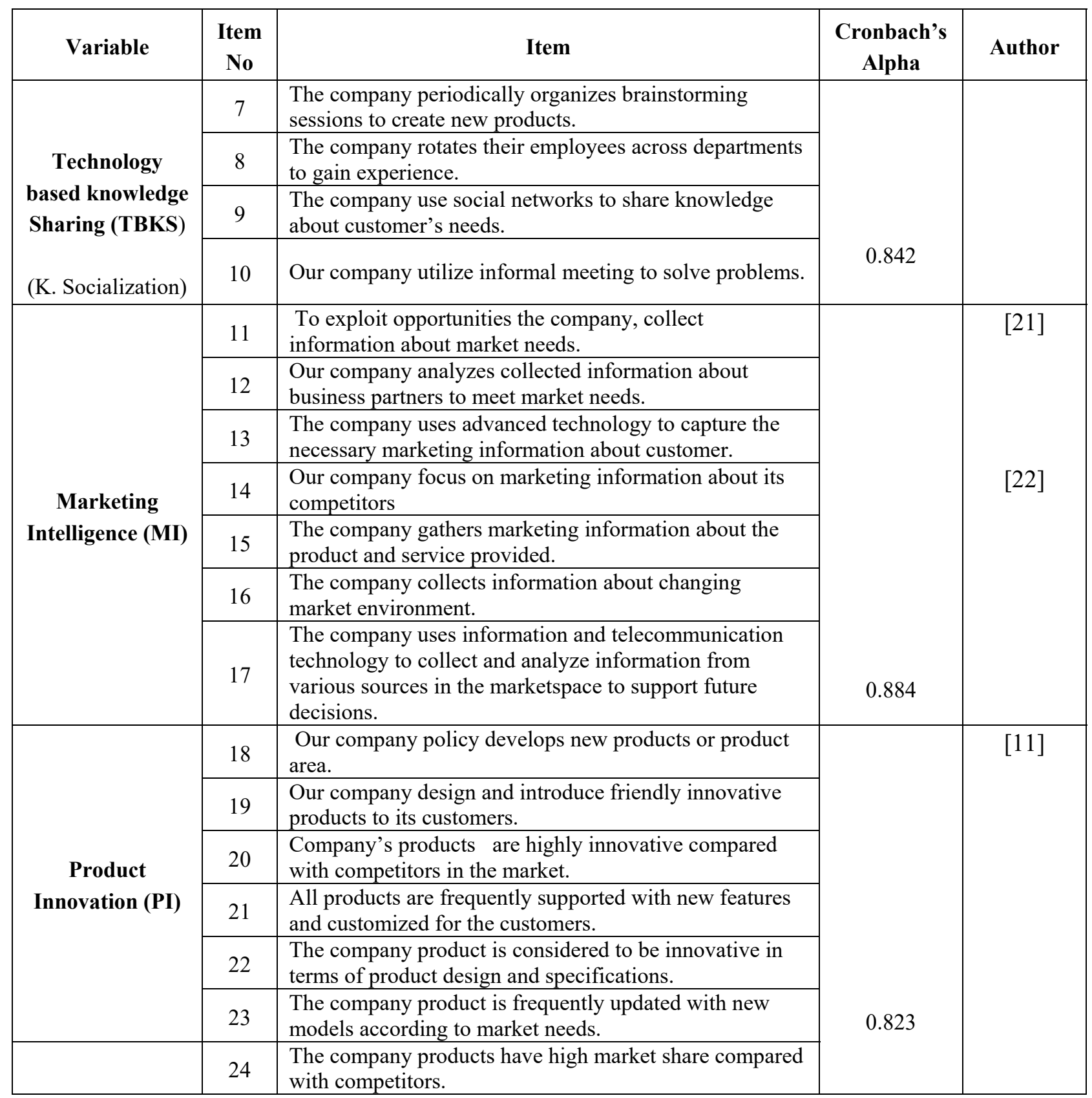

\section{Data Analysis and Discussions}

\subsection{Descriptive statistics}

Table (2) shows the variables statistics mean. The mean of all variables is high due to the fact that pharmaceutical companies in Jordan is considered the pioneer sector in Jordanian economy.

Table 2. Means of participants' responses on the study variables

\begin{tabular}{|c|c|c|c|}
\hline Variable & Mean & $\begin{array}{c}\text { Importance } \\
\text { level }\end{array}$ & Rank \\
\hline (TBKS) & 4.14 & High & 1 \\
\hline$(\mathrm{MI})$ & 3.81 & High & 3 \\
\hline (PI) & 3.97 & High & 2 \\
\hline
\end{tabular}

\subsection{Regression Analysis}

To examine the first three hypotheses, regression Analysis among variables shown that Technology based knowledge sharing $(\beta=0.758, p<0.001)$ and marketing intelligence $(\beta=0.0 .767, p<0.001)$ are positively significant related to product innovation. Moreover, Technology based knowledge sharing $(\beta=0.778, \quad p<0.001)$ has significantly impact on marketing intelligence. Table (3) shows that, H1, H2, and $\mathrm{H} 3$ hypotheses are supported. 
Table 3. Regression Analysis among variables

\begin{tabular}{|l|c|c|c|c|c|}
\hline \multicolumn{1}{|c|}{ hypotheses } & $\boldsymbol{\beta}$ & $\mathbf{R}^{\mathbf{2}}$ & $\mathbf{F}$ & Sig. & Result \\
\hline H1: (TBKS) has a significant impact on (MI) & $0.778^{* * *}$ & 0.608 & 799.112 & 0.000 & Supported \\
\hline H2: (TBKS) has a significant impact on (PI). & $0.758^{* * *}$ & 0.547 & 619.351 & 0.000 & Supported \\
\hline H3: (MI) has a significant impact on (PI). & $0.767 * * *$ & 0.551 & 624.228 & 0.000 & Supported \\
\hline
\end{tabular}

$* \mathrm{p}<0.05, * * \mathrm{p}<0.01, * * * \mathrm{p}<0.001$.

\subsection{Mediation Test}

To examine the fourth hypothesis, regression analysis was used to investigate the mediation impact of marketing intelligence between Technology based knowledge sharing (TBKS) and product innovation (PI). The first model, the study deal with Technology based knowledge sharing as independent variable and marketing intelligence as dependent variable. The results show that Technology based knowledge sharing has significantly impact on Marketing Intelligence $(\beta=0.778, p<0.001)$. The Second model, Technology based knowledge sharing and marketing intelligence are the independent variables, and product innovation is the dependent variable. The results indicate that Technology based knowledge sharing has a significant impact on product innovation $(\beta=$ $0.758, \mathrm{p}<0.001$ ), and marketing intelligence has a significant impact on product innovation $(\beta=0.767$, $\mathrm{p}<0.001)$.The third model, Technology based knowledge sharing and marketing intelligence regressed with product innovation ( $\beta=0.408$, $\mathrm{p}<0.001 ; \beta=0.413, \mathrm{p}<0.001)$. The result shows that $\beta$ value of Technology based knowledge sharing is reduced from 0.758 to 0.413 , and both Technology based knowledge sharing and marketing intelligence are significantly related to product innovation. Thus, the fourth Hypothesis (H4) is supported, showing that marketing intelligence has partial mediating impact between Technology based knowledge sharing and product innovation as shown in table (4).

Table 4. Mediation test of marketing intelligence in the relationship between technology-based knowledge sharing and product innovation

\begin{tabular}{|c|c|c|c|c|}
\hline \multirow{2}{*}{ Variables } & \multirow{2}{*}{$\begin{array}{c}\text { Model } 1 \\
\text { MI }\end{array}$} & \multicolumn{2}{|c|}{ Model 2} & \multirow{2}{*}{$\begin{array}{c}\text { Model } 3 \\
\text { PI }\end{array}$} \\
\hline & & PI & PI & \\
\hline (TBKS) & $\begin{array}{c}0.778 * * * \\
(0.000)\end{array}$ & $\begin{array}{c}0.758 * * * \\
(0.000)\end{array}$ & & $\begin{array}{c}0.408^{* * *} \\
(0.000)\end{array}$ \\
\hline MI & & & $\begin{array}{c}0.767 * * * \\
(0.000) \\
\end{array}$ & $\begin{array}{c}0.413^{* * *} \\
(0.000) \\
\end{array}$ \\
\hline $\mathrm{R} 2$ & 0.608 & 0.547 & 0.551 & 0.591 \\
\hline Adj R2 & 0.596 & 0.520 & 0.523 & 0.604 \\
\hline $\mathrm{F}$ & 799.112 & 619.351 & 624.228 & 404.799 \\
\hline
\end{tabular}

$* \mathrm{p}<0.05,{ }^{*} \mathrm{p}<0.01, * * * \mathrm{p}<0.001$

\section{Conclusions and Recommendations}

The purpose of this study is to enrich the literature linking technology-based knowledge sharing with marketing intelligence and product innovation, and to investigate the extent to which technology-based knowledge sharing influence on product innovation, at the same time determining the mediation role of marketing intelligence in Jordanian pharmaceutical companies. According to findings of the study there are significant impacts of technology-based knowledge sharing and marketing intelligence on product innovation, and there is a significant impact of technology-based knowledge sharing on marketing intelligence which has partially mediation role in the relationship between technology-based knowledge sharing and product innovation.
However, the findings of study correspond with previous theoretical deductions which indicate that knowledge sharing and marketing intelligence have a key role to achieve product innovation. Based on study findings managers should be taking into account the importance of using information technology in knowledge sharing as well as marketing intelligence to enhance product innovation for bigger market share. Therefore, this shed light on knowledge sharing systems and marketing intelligence to create innovative products. Finally, future researches could be applied in different sectors through using qualitative approach. 


\section{References}

[1]. Fernandez, I. B., Gonzalez, A., \& Sabherwal, R. (2004). Knowledge Management-Challenges, Solutions and Technologies. Ney Jersey: Pearson Education.

[2]. Nonaka, I., \& Nishiguchi, T. (2001). Knowledge emergence: Social, technical, and evolutionary dimensions of knowledge creation. Oxford University Press.

[3]. Cerchione, R., Esposito, E., \& Spadaro, M. R. (2016). A literature review on knowledge management in SMEs. Knowledge Management Research \& Practice, 14(2), 169-177.

[4]. Flanagin, A. J. (2002). The elusive benefits of the technological support of knowledge management. Management Quarterly, 16(2), 242-248.

[5]. Alavi, M., \& Leidner, D. E. (2001). Knowledge management and knowledge management systems: Conceptual foundations and research issues. MIS quarterly, 107-136.

[6]. Filippov, S., \& Iastrebova, K. (2010). Managing information overload: organizational perspective. Journal on Innovation and Sustainability, 1(1), 121-38.

[7].Aalbers, H. L. (2012). Organizing intra-organizational networks for innovation. Groningen: Rijksuniversiteit Groningen.

[8]. Cummings, J. N. (2004). Work groups, structural diversity, and knowledge sharing in a global organization. Management science, 50(3), 352-364.

[9]. Jasimuddin, S. M., Klein, J. H., \& Connell, C. (2005). The paradox of using tacit and explicit knowledge: Strategies to face dilemmas. Management decision, 43(1), 102-112.

[10]. Haas, M. R., \& Hansen, M. T. (2005). When using knowledge can hurt performance: The value of organizational capabilities in a management consulting company. Strategic management journal, 26(1), 1-24.

[11]. Tohidi, H., \& Jabbari, M. M. (2012). Product innovation performance in organization. Procedia Technology, 1, 521-523.
[12]. Chiou, T. Y., Chan, H. K., Lettice, F., \& Chung, S. H. (2011). The influence of greening the suppliers and green innovation on environmental performance and competitive advantage in Taiwan. Transportation Research Part E: Logistics and Transportation Review, 47(6), 822-836.

[13]. Nwokah, N. G., \& Ondukwu, F. E. (2009). Competitive intelligence and marketing effectiveness in corporate organizations in Nigeria. African Journal of Marketing Management, 1(1), 010-022.

[14]. Queiroz, J. P. D., \& Oliveira, B. (2014). Benefits of the marketing information system in the clothing retail business. JISTEM-Journal of Information Systems and Technology Management, 11(1), 153-168.

[15]. Igbaekemen, G. O. (2014). Marketing intelligence as a strategic tool for competitive edge. British Journal of Marketing Studies, 2(5), 17-34.

[16] Urbancova, H. (2013). Competitive advantage achievement through innovation and knowledge. Journal of competitiveness, 5(1), 82-84.

[17]. Bakar, L. J. A., \& Ahmad, H. (2010). Assessing the relationship between firm resources and product innovation performance. Business Process Management Journal, 16(3), 420-435.

[18]. Wang, C. L., \& Ahmed, P. K. (2004). The development and validation of the organisational innovativeness construct using confirmatory factor analysis. European journal of innovation management,7(4), 303-313.

[19]. Franco, M., \& Mariano, S. (2007). Information technology repositories and knowledge management processes. Vine: The Journal of Information and Knowledge Management Systems 37(4), 440-45.

[20]. Becerra-Fernandez, I., Gonzalez, A., \& Sabherwal, R. (2004). Knowledge Management and KM Software Package, Prentice Hall.

[21]. Al-Weshah, G. A. (2017). Marketing intelligence and customer relationships: empirical evidence from Jordanian banks. Journal of Marketing Analytics, 5(3-4), 141-152.

[22]. Williams, J. E., \& Chaston, I. (2004). Links between the linguistic ability and international experience of export managers and their export marketing intelligence behaviour. International Small Business Journal, 22(5), 463-486. 